\title{
Evaluation of the penetration of ciprofloxacin and amoxycillin into the bronchial mucosa
}

\author{
D HONEYBOURNE, J M ANDREWS, J P ASHBY, R LODWICK, R WISE \\ From the Departments of Thoracic Medicine and Microbiology, Dudley Road Hospital, Birmingham
}

\begin{abstract}
The concentrations of two antibiotics, amoxycillin and ciprofloxacin, were measured by microbiological assay in serum and in bronchial mucosa obtained at fibreoptic bronchoscopy in 38 patients undergoing diagnostic bronchoscopy for a range of respiratory symptoms. Patients had taken one of the two drugs orally for four days before bronchoscopy. The percentage penetration of antibiotic from serum to bronchial mucosa was calculated as the ratio of drug concentration in bronchial tissue to that in serum $\times 100$. Of the nine patients who took amoxycillin $500 \mathrm{mg}$ thrice daily the mean (SD) percentage penetration was 75 (32). This was significantly lower than the mean percentage penetration of $147(85)$ in 29 patients who took ciprofloxacin $500 \mathrm{mg}$ twice daily. Ten patients were given a single intravenous dose of ciprofloxacin $200 \mathrm{mg}$ one hour before bronchoscopy and the mean percentage penetration was $231(84)$. This study has shown that the quinolone antibiotic ciprofloxacin is concentrated in the bronchial mucosa.
\end{abstract}

\section{Introduction}

When the potential effectiveness of an antibiotic for respiratory infections is assessed sputum concentrations of the drug are often measured. Many antibiotics, however, do not penetrate well into sputum $^{1}$ and concentrations vary because of the diverse and unpredictable factors affecting bronchial secretions. $^{2}$ Knowledge of the penetration of an antibiotic into bronchial mucosa and lung tissue may be more relevant. Obtaining lung tissue is obviously difficult and many studies have relied on measurement of antibiotic concentrations in samples of lung removed by thoracic surgeons-for example, for lung cancer. We have obtained samples of bronchial mucosa during fibreoptic bronchoscopy from patients pretreated with amoxycillin or the quinolone antibiotic ciprofloxacin and measured mucosal concentrations of the two drugs. In our experience bronchial biopsy samples consist mainly of mucosa, although a very small amount of submucosal tissue may also be present. We included a quinolone antimicrobial because recent work has shown that the drug is concentrated in the mucosa of the gastrointestinal ( $R$ Wise, unpublished observations) and genitourinary

Address for reprint requests: Dr D Honeybourne, Department of Thoracic Medicine, Dudley Road Hospital, Birmingham B18 7QH.

Accepted 1 June 1988 tracts, ${ }^{3}$ and data on the quinolone enoxacin ${ }^{4}$ suggests that the same is true for the respiratory mucosa. The results obtained with ciprofloxacin have been compared with those obtained with amoxycillin.

\section{Methods}

Patients who were undergoing diagnostic fibreoptic bronchoscopy were asked if they would agree to take an antibiotic (amoxycillin or ciprofloxacin) for four days before bronchoscopy and to have mucosal biopsies as well as the routine diagnostic biopsy. Patients gave written informed consent and the protocol was approved by the local ethical committee. The patients were not taking any other drugs known to influence antibiotic transport from the blood into bronchial tissue.

Study 1 Nine men (mean age 62 (SD 8.3) years) took oral amoxycillin $500 \mathrm{mg}$ thrice daily for four days before bronchoscopy. Excluded from the study were those known to be allergic to $\beta$ lactam antibiotics and those with severe cardiac, renal, or hepatic impairment. The time of the last dose was noted.

Study 2 Oral ciprofloxacin was given to 29 patients, of whom 21 were male (mean age 66 (SD 12.4) years). Excluded from this study were those known to have a sensitivity to quinolones; those with severe cardiac, renal, or hepatic impairment or having concomitant theophylline treatment (as quinolones reduce the hepatic clearance of theophylline); pregnant or lactat- 
ing women; and patients with a history of epilepsy. The patients took $500 \mathrm{mg}$ oral ciprofloxacin twice daily for four days before bronchoscopy, the last dose being taken on the morning of bronchoscopy. The time of the last dose was recorded.

Study 3 Ten patients (five male: mean age 60 (SD 11) years) received an intravenous infusion of $200 \mathrm{mg}$ ciprofloxacillin in $100 \mathrm{ml}$ over 30 minutes on the day of the bronchoscopy.

All subjects in studies 1 and 3 and 19 subjects in study 2 were given a standard premedication of $10 \mathrm{mg}$ morphine and $0.6 \mathrm{mg}$ atropine one hour before bronchoscopy. The last 10 subjects in study 2 were given no premedication but instead had $5 \mathrm{mg}$ intravenous midazolam at the beginning of the bronchoscopy procedure. All subjects in all three studies were given $4 \mathrm{ml} 4 \%$ lignocaine by nebuliser 20 minutes before the procedure. Topical lignocaine was also given during bronchoscopy.

In addition to the samples taken for diagnostic purposes, bronchial biopsy samples were taken from both lungs via the fibreoptic bronchoscope for estimation of antibiotic concentrations. Three biopsy samples were taken from the subcarina between the right upper lobe and the bronchus intermedius, and three from the subcarina between the left upper and lower lobes. Samples were not used if they appeared to be abnormal macroscopically. Samples from the two lungs of each patient were subsequently processed and analysed separately. Venous blood was taken at the same time for assay of the serum concentration of the antibiotic and the time since the last dose of antibiotic was noted.

Biopsy samples were taken immediately to the laboratory and placed in a humidity chamber to prevent loss of moisture. Bloodstained samples were discarded. After the tissue had been weighed in a preweighed glass tube $200 \mu \mathrm{l}$ of chilled phosphate buffer (pH 7.0) was added. The tube was placed "on ice" before ultrasonication for two minutes at $50 \%$ duty cycle (W225 Sonicator, Heat Systems Ultrasonics Inc). Both serum and tissue samples were assayed by a plate diffusion technique. The indicator organisms were as follows: amoxycillin-Sarcia lutea (ATCC 9341); ciprofloxacin-Escherichia coli 4004 (obtained from Bayer AG, Wuppertal, West Germany). The media used were IsoSensitest agar, pH 7.4 (Oxoid,
Basingstoke, UK) for ciprofloxacin and Antibiotic Medium No 1, pH 6.6 (Oxoid) for amoxycillin.? Standards were prepared in human serum for the assay을 of serum samples and phosphate buffer $(\mathrm{pH} 7.0$ for ciprofloxacin and $\mathrm{pH} 6.6$ for amoxycillin) for tissue $\underset{\Omega}{\Phi}$ concentrations. The lower limits of sensitivity (LLS)零 and coefficient of variation (CV) of the assays are as follows: ciprofloxacin-LLS $=0.03 \mathrm{mg} / 1, \mathrm{CV}=$ ? $6.8 \%$; amoxycillin-LLS $=0.03 \mathrm{mg} / \mathrm{l}, \mathrm{CV}=7.2 \% \cdot \overrightarrow{\vec{\omega}}$ The concentration of antimicrobial in the tissueo sample was calculated as follows:

$$
\begin{aligned}
& \frac{\text { conc. assayed }(\mu \mathrm{g} / \mathrm{ml}) \times 1000}{\text { weight }(\mathrm{mg})} \times \frac{\begin{array}{l}
\text { diluent } \\
\text { volume }
\end{array}+\begin{array}{c}
\text { sample } \\
\text { volume }
\end{array}}{1000} \\
& =\text { tissue concentration }(\mathrm{mg} / \mathrm{kg} \text { tissue }) .
\end{aligned}
$$

The percentage penetration of antibiotic into bron-? chial tissue was calculated for each subject as follows: $(s)$

$$
\frac{\text { bronchial tissue drug concentration }(\mathrm{mg} / \mathrm{kg})}{\text { serum drug concentration }(\mathrm{mg} / \mathrm{l})} \times 100 \text {. }
$$

The percentage penetrations of amoxycillin and ciprofloxacin were analysed separately for each lung $\overrightarrow{0}$ and the overall mean penetration was calculated foroo each subject. The results with amoxycillin and ciprofloxacin were compared by Student's $t$ test.

\section{Results}

In study 1 samples were taken 3.12-4.08 hours after the last dose of amoxycillin (mean time $3 \cdot 5$ hours). The mean percentage penetration from serum to bronchia tissue (ratio of serum to bronchial tissue concentra? tion) was 75 (table).

In study 2 samples were taken 2-7 hours after the्ठ last dose of ciprofloxacin (mean 3.9 hours). The mean percentage penetration of ciprofloxacin from serum too bronchial mucosa was 147 (table). This was higher than the mean percentage penetration of amoxycilling (75) $(p<0.001)$, and the same was true when each lung was analysed separately (for left lung $p<0.00$ lo and for right lung $p<0.01$ ). The correlation between the drug concentrations in the biopsy sample and ine serum was $0.68(p<0.01)$.

In study 3 samples were taken $0 \cdot 33-2$ hours after the end of the half hour infusion of ciprofloxacin (mear 5 time 0.97 hours). The mean percentage penetration of

\begin{tabular}{|c|c|c|c|c|}
\hline & $\begin{array}{l}\text { Biopsy weight } \\
\text { per patient (mg) }\end{array}$ & $\begin{array}{l}\text { Serum concentration } \\
(\mathrm{mg} / \mathrm{l})\end{array}$ & $\begin{array}{l}\text { Tissue concentration } \\
(\mathrm{mg} / \mathrm{kg})\end{array}$ & $\%$ penetration \\
\hline $\begin{array}{l}\text { Oral amoxycillin }(n=9) \\
\text { Oral ciprofloxacin }(n=29) \\
\text { Intravenous ciprofloxacin }(n=10)\end{array}$ & $\begin{array}{l}5 \cdot 05(1 \cdot 47) \\
6 \cdot 50(2 \cdot 5) \\
9 \cdot 61(2 \cdot 32)\end{array}$ & $\begin{array}{l}4.13(2 \cdot 37) \\
3.01(1 \cdot 67) \\
1.62(0 \cdot 79)\end{array}$ & $\begin{array}{l}2.68(1 \cdot 24) \\
4 \cdot 40(3 \cdot 26) \\
3 \cdot 94(2 \cdot 50)\end{array}$ & $\begin{array}{r}75(32) \\
147(85) \\
231(84)\end{array}$ \\
\hline
\end{tabular}

Mean (SD) concentrations of ciprofloxacin and amoxycillin in bronchial tissue and serum 
ciprofloxacin from serum to bronchial mucosa was 231 (table).

\section{Discussion}

The bronchial mucosa is probably the main site of acute bacterial infection and inflammation in patients with chronic bronchitis and bronchiectasis ${ }^{5}$ and one of the sites affected in bronchopneumonia. Hence antimicrobials that reach a concentration in the bronchial mucosa higher than that required to inhibit invading pathogens might be assumed to be more effective in treatment than those with lower concentrations. This study has measured concentrations in bronchial mucosa samples from patients and related them to serum concentrations. The absolute drug concentrations in bronchial mucosa and their relation to serum concentrations expressed as percentage penetration may be more relevant than sputum concentrations. Measurements of antibiotic concentrations in sputum are difficult to interpret because various factors may affect them. Sputum is often diluted with saliva, in which the concentration of antibiotic is usually lower than that in the sputum. ${ }^{67}$ Particular problems may arise when sputum concentrations are compared with serum concentrations at a particular time after a dose of antibiotic. Respiratory secretions will pool in the lung and lead to an averaging of sputum antibiotic concentrations, ${ }^{2}$ so that the peak sputum concentration will not be measured and cannot be related to the minimum inhibitory concentration of an organism. The

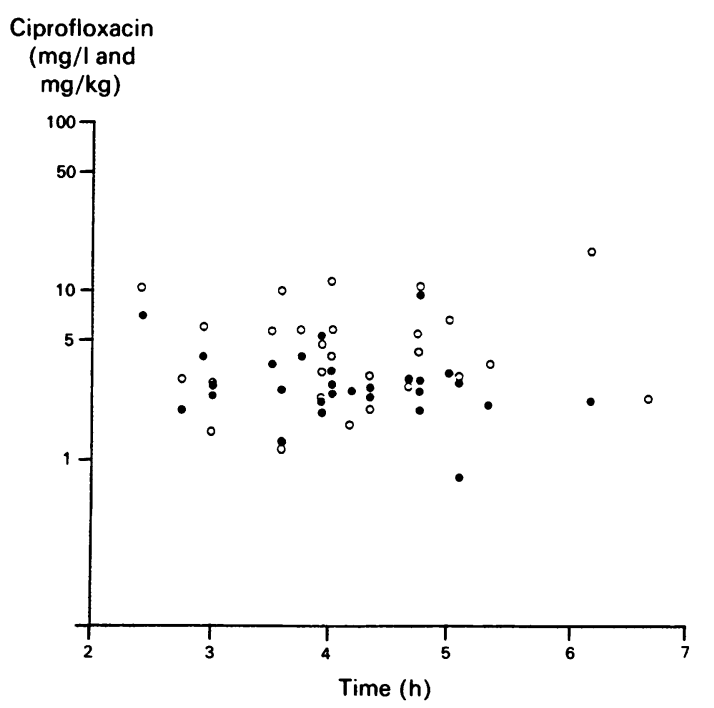

Mean ciprofloxacin serum $(\bullet, m g / l)$ and bronchial $(0, \mathrm{mg} / \mathrm{kg}$ ) concentrations after $500 \mathrm{mg}$ twice daily. apparent lack of correlation of sputum and serum concentrations found by some workers' may be partly due to this effect of pooling. Antibiotics may be unstable in bronchial secretions ${ }^{8}$ owing to change in temperature, $\mathrm{pH}$, or protein content. These factors may explain why lung tissue concentrations of antibiotic show a much better correlation than sputum concentrations. ${ }^{9}$ For similar reasons bronchial secretions obtained at bronchoscopy will be diluted by the lignocaine used as the local anaesthetic or affected by the atropine commonly used as premedication and the pooling of respiratory secretions.

Bronchial tissue concentration can be estimated by accepting that a gradient exists from blood through bronchial tissue to sputum. This would occur if the only process were passive diffusion. The rate of penetration of antibiotics from blood to bronchial secretions is, however, known to vary considerably from one drug to another even within the same group of antibiotics - for example, amoxycillin appears to penetrate into bronchial secretions better than ampicillin.' Physicochemical properties of antibiotics appear to be important in determining their penetration into bronchial tissue and lung secretions. Lipophilic antibiotics are known to accumulate in lung tissue to a greater extent than lipid insoluble drugs such as penicillins and cephalosporins. ${ }^{10}$ Protein binding of antibiotics is probably important also, highly protein bound antibiotics passing the "blood-bronchus" barrier with difficulty. In the presence of infection and bronchial inflammation some antibiotics appear to have enhanced penetration into bronchial secretions.' This may be at least partly related to the increased leak of protein from bronchial tissue into bronchial secretions, which may be carrying with it more protein bound antibiotic. ${ }^{9}$

Prolonged antibiotic treatment may lead to increased antibiotic binding to tissue, as shown for gentamicin and amikacin." It may account for the high concentrations of the quinolone enoxacin that were found in bronchial tissue, ${ }^{4}$ with a much higher percentage penetration into bronchial tissue from serum than we found for ciprofloxacin. This may in part be due to the different methods used to assay the antibiotic in bronchial tissue. Our study used a microbiological technique whereas the enoxacin study used high performance liquid chromatography. This measures drug concentrations directly but may also measure inactive antibiotics whereas microbiological assays measure total inhibitory activity from whatever source, some of which may not be due to the antibiotic. If there is avid binding of quinolones within the bronchial mucosa then microbiological assays may give lower drug concentrations than high performance liquid chromatography. Structural differences between enoxacin and ciprofloxacin may also influence 
tissue penetration; both exist as zwitterions at physiological pH and this may increase the possibility of active transport into the bronchial mucosa. ${ }^{4}$ In one study on homogenised whole lung there was substantial lung penetration after a single preoperative dose of ciprofloxacin, ${ }^{12}$ varying from $195 \%$ to $1017 \%$.

The technique of obtaining bronchial mucosa at fibreoptic bronchoscopy to measure antibiotic concentrations has been used to assess the penetration of the $\beta$ lactam piperacillin. ${ }^{13}$ When multiple doses of ciprofloxacin were administered the percentage penetration varied (mean value $147 \%$ ) but was greater than that of the $\beta$ lactam. In our study, as the figure shows, bronchial tissue concentrations of ciprofloxacin had reached a steady state after four days of treatment as there was no correlation between the antibiotic concentration and the interval since the last dose of antibiotic. Several studies have shown greater success in eradicating organisms causing lower respiratory tract infections with ciprofloxacin than with amoxycillin or ampicillin. ${ }^{1415}$

The variability in antibiotic penetration between patients may in part be due to blood contamination. Heavily bloodstained biopsy specimens were discarded but small amounts would not be detected and would tend to affect the overall penetration values.

Ciprofloxacin showed a greater penetration into bronchial mucosa and less intersubject variation after a single intravenous infusion than after multiple oral doses. The less variable results may be related to more accurate dosing as medical staff administered the intravenous dose whereas patients self administered the oral dose. Ciprofloxacin penetrates bronchial mucosa very rapidly, the mean bronchial mucosal concentration being more than twice the serum level one hour, on average, after administration. This rapid penetration and concentration of ciprofloxacin into bronchial mucosa suggest that it should be very effective against infection at this site. The clinical significance of our findings can be related to the minimum inhibitory concentrations for common respiratory pathogens.

The minimum concentration of ciprofloxacin inhibiting $90 \%$ of organisms $\left(\mathrm{MIC}_{90}\right.$ ) is $0.01 \mathrm{mg} / \mathrm{l}$ for Haemophilus influenzae and very low for Staphylococcus aureus, Klebsiella pneumonia, Escherichia coli, Branhamella catarrhalis, Legionella $\mathrm{spp}$, and Mycoplasma pneumoniae. ${ }^{1617}$ The $\mathrm{MIC}_{90}$ of ciprofloxacin may, however, approach $1 \mathrm{mg} / \mathrm{ml}$ for Pseudomonas aeruginosa and $2 \mathrm{mg} / \mathrm{l}$ for Streptococcus pneumoniae. ${ }^{18}$ Our study has shown mucosal concentrations of around $4.4 \mathrm{mg} / \mathrm{kg}$, which is higher than the sputum concentrations reported by other workers. ${ }^{19}$ This suggests that ciprofloxacin may be effective in vivo against these pathogens. Interestingly, in patients with cystic fibrosis sputum concentrations have been found to be higher than serum concentrations. ${ }^{20}$

The concentration of ciprofloxacin that we have found in bronchial mucosa has also been found in the $\frac{\bar{\sigma}}{\bar{D}}$ mucosa of the gastrointestinal tract (penetration $\frac{\mathrm{O}}{\widehat{D}}$ $240 \%$ ) and in the fallopian tubes (penetration $350 \%$ ). $\stackrel{\mathbb{Q}}{\square}$ The mechanisms concerned in the concentration of $\nRightarrow$ quinolones in the mucosa and the clinical relevance $\vec{\circ}$ merit further research.

We thank Dr J Herbert of Bayer for his support and Mr W A Davis of the West Midlands Regional Health Authority information department for his statistical advice.

\section{References}

1 Bergogne-Berezin E. Penetration of antibiotics into the $\vec{c}$ respiratory tree. J Antimicrob Chemother 1981;8:171-4.

2 Pennington JE. Penetration of antibiotics into respiratory secretions. Rev Inf Dis 1981;3:67-73.

3 Dalholl A, Weuta H. Penetration of ciprofloxacin into gynaelogic tissues. Am J Med 1987;82(suppl A):133-8.

4 Malin GE, Braude PD, Whelon AJ, Somogyi AA. Penetration of enoxacin into human bronchial mucosa. $\infty$ Am Rev Respir Dis 1986;134:1209-12.

5 Hers JGP, Mulder J. The mucosal epithelium of the respiratory tract in mucopurulent bronchitis caused by Haemophilus influenzae. J Pathol Bacteriol 1953; 66:103-8.

6 Stewart SM, Fisher M, Young JE, Lutz W. Ampicillin levels in sputum, serum and saliva. Thorax 1970; $\overline{\vec{B}}$ 25:304-11.

7 Simon C, Gatzemeier V. Serum and sputum levels of cefaclor. Postgrad Med J 1979;55(suppl 4):30-4.

8 Marlin GE, Nicholls AJ, Funnell GR, Bradbury R. Penetration of cefaclor into bronchial mucosa. Thorax 1984:39:813-7.

9 Thadepalli H. Lower respiratory tract. In: Ristuccia AM, Cunha BA, eds. Antimicrobial therapy. New York: Raven, 1984:439-54.

10 Biagi GL, Guerra MC, Barbaro AM, Gamba MF. Influence of lopophilic character of the antibacterial activity of cephalosporins and penicillins. $J$ Med Chem $\circ$ 1970;13:511-6.

11 Kornguth ML, Kunin CM. Distribution of gentamicin and amikacin in rabbit tissue. Antimicrob Agents Chemother 1977:11:974-7.

12 Schlenkhoff D, Mayer M, Dalhoff A. Penetration of ciprofloxacin into human lung tissue following a single 0 intravenous dose. In: Ishigami J, ed. Recent advances in $\mathrm{\omega}$ chemotherapy. Proceedings of the 14th International 0 Congress of Chemotherapy, Kyoto, 1985. Tokyo: University of Tokyo Press, 1985: 1620-1.

13 Marlin GE, Burgess KR, Burgoyne J, Furrell GR, Guinness MDG. Penetration of piperacillin into bronchial mucosa and sputum. Thorax 1981;36:774-80.

14 Gleadhill IC. Ferguson WP. Lowry RC. Efficacy and safety of ciprofloxacin in patients with respiratory infections in comparison with amoxycillin. $J \stackrel{\mathbb{Q}}{\mathbb{Q}}$ Antimicrob Chemother 1986;18(suppl D):133-8. 
15 Wollschlager CM, Raoof S, Khan FA, Guarneri JJ, LaBombardi V, Afzal Q. Controlled comparative study of ciprofloxacin versus ampicillin in treatment of bacterial respiratory tract infections. Am J Med 1987;82(suppl 4A):164-8.

16 King A, Phillips I. The comparative in-vitro activity of eight newer quinolones and nalidixic acid. $J$ Antimicrob Chemother 1986;18(suppl D):1-20.

17 Fass RJ. Efficacy and safety of oral ciprofloxacin in the treatment of serious respiratory infections. Am J Med 1987;82(suppl 4A):202-7.

18 Wise R, Andrews JM, Edwards LJ. In vitro activity of
Bay 09867, a new quinolone derivative, compared with that of other antimicrobial agents. Antimicrob Agents Chemother 1983;23:559-64.

19 Thys JP, Klastersky J, Jacobs F, et al. Penetration of ciprofloxacin into bronchial secretions and pleural fluid. In: Neu HC, Weuta H, eds. Proceedings of the $1 s t$ International Ciprofloxacin Workshop. Amsterdam: Excerpta Medica, 1986:153-6.

20 Goldforb H, Stern RC, Reed MD, Yamashita TS, Myers CM, Blurner JL. Ciprofloxacin monotherapy for acute pulmonary exacerbations of cystic fibrosis. Am J Med 1987;82(suppl 4A):174-9. 